Aletria, Belo Horizonte, v. 27, n. 2, p. 241-260, 2017

\title{
Écfrase arquitetônica: um modelo interpretativo
}

\section{Architectural Ekphrasis: an Interpretative Model}

Miriam de Paiva Vieira

Universidade Federal de São João del-Rei, São João del-Rei, Minas Gerais / Brasil miriamvieira@gmail.com

Resumo: A écfrase é um dos possíveis procedimentos midiáticos que trata do cruzar de fronteiras entre a literatura e a arquitetura. O objetivo deste ensaio é apresentar um modelo interpretativo para a tipologia écfrase arquitetônica. Tal modelo será ilustrado pelas biografias romanceadas inspiradas na vida e obra da poeta Elizabeth Bishop e da arquiteta autodidata Lota Macedo Soares, intituladas Flores raras e banalissimas: a história de Lota de Macedo Soares e Elizabeth Bishop (1995), de Carmen Oliveira, e $A$ arte de perder (2011), de Michael Sledge.

Palavras-chave: écfrase arquitetônica; literatura; arquitetura; Carmen Oliveira; Michael Sledge; Elizabeth Bishop; Lota Macedo Soares.

Abstract: Architectural ekphrasis is one of the possible medial procedures in the crossing of borders from architecture to literature. The aim of this essay is to present an interpretative model developed to the study of architectural ekphrasis. The proposed model will be illustrated by the Künstlerromane Flores raras e banalissimas: a história de Lota de Macedo Soares e Elizabeth Bishop (1995), by Brazilian Carmen Oliveira, and The More I Owe You (2010), by American Michael Sledge.

Keywords: architectural ekphrasis; literature; architecture; Carmen Oliveira; Michael Sledge; Elizabeth Bishop; Lota Macedo Soares.

A importância da arquitetura no relacionamento da poeta norteamericana Elizabeth Bishop e da empreendedora brasileira Lota de Macedo Soares - responsável pela concepção de sua casa em Petrópolis, 
conhecida como Samambaia, e pela execução do Parque do Aterro do Flamengo, no Rio de Janeiro - é evidenciada em várias das obras que compõem a fortuna crítica de Elizabeth Bishop. É por meio do fenômeno midiático denominado écfrase ${ }^{1}$ que a arquitetura se faz presente em duas biografias romanceadas inspiradas não somente na vida e obra de Bishop, mas também na vida e obra de sua companheira Lota, e no cenário da arquitetura modernista brasileira.

O objetivo deste ensaio é apresentar um modelo interpretativo para a tipologia écfrase arquitetônica, elaborado a partir da definição das características relevantes para a compreensão das especificidades da mídia arquitetura em uma écfrase. Norteada pelo estudo de transferência de características de mídias, aliada às noções de perspectiva e corporeidade e ainda à retomada dos conceitos de enargia ${ }^{2}$ e periegesis, essa proposta compreende quatro tipos de écfrases arquitetônicas: contemplativa, performativa, simbólica e técnica. Tais tipologias serão ilustradas pelas biografias romanceadas inspiradas na vida e obra da poeta Elizabeth Bishop e da arquiteta autodidata Lota Macedo Soares: Flores raras e banalíssimas: a história de Lota de Macedo Soares e Elizabeth Bishop (1995), de Carmen Oliveira, e A arte de perder (2011), de Michael Sledge. Como o termo "écfrase" não costuma aparecer junto à palavra "arquitetura", poucas são as obras teóricas ${ }^{3}$ que tratam do termo "écfrase arquitetônica". A arquitetura é definida, por Beatriz Colomina, como um ato interpretativo e crítico. Assim como Leon Battista Alberti (1435) sugere que Narciso tenha sido o inventor da pintura, Beatriz Colomina lê o mito de Ariadne como uma decifradora e, por conseguinte, a arquiteta do labirinto. ${ }^{4}$ Entretanto, apesar de concordar com a premissa

\footnotetext{
${ }^{1}$ Sobre como a écfrase, recurso retórico utilizado na Antiguidade, foi incorporada pelos estudos da intermidialidade na contemporaneidade como um fenômeno midiático, ver: VIEIRA. Écfrase: de recurso retórico na antiguidade a fenômeno midiático na contemporaneidade, p. 45-57.

${ }^{2}$ Sobre a importância do resgate da enargeia, ou enargia, nos estudos contemporâneos da écfrase, ver: VIEIRA. Écfrase: de recurso retórico na antiguidade a fenômeno midiático na contemporaneidade, p. 49-51.

${ }^{3}$ Entre elas, citamos o artigo de Stephanie Glaser (2017) sobre écfrase arquitetônica de catedrais góticas em diferentes gêneros literários e a seção sobre a verbalização da fachada da casa de Heathcliff em $O$ morro dos ventos uivantes, trecho que Liliane Louvel (2010) denomina écfrase arquitetônica.

${ }^{4}$ COLOMINA. Architectureproduction, p. 7.
} 
de Colomina, Karsten Harries pede cautela na distinção entre arquitetura, arquitetura verbal e metáforas arquitetônicas; ${ }^{5}$ afinal, o fato de Ariadne decifrar a arquitetura com a ajuda de um fio, não faz dela a arquiteta do labirinto, ${ }^{6}$ ou seja, a écfrase é uma das formas de a literatura verbalizar a arquitetura, mas, obviamente, nunca chegará a ser a arquitetura per $s e$. As questões teóricas acerca de interpretação e recepção contribuem para a aproximação do diálogo entre teoria da arquitetura e os estudos sobre écfrase. Por um lado, a recepção do usuário da edificação deve ser considerada durante o processo de elaboração do projeto; no entanto, o envolvimento desse usuário no ato de interpretação da edificação não faz dele coautor do projeto de arquitetura. Por outro lado, de acordo com o referencial teórico aqui utilizado, a écfrase só acontece no ato de interpretação, naquele momento déjà $v u$ em que o leitor e a fonte visual - seja uma pintura ou uma obra arquitetônica - interagem através do texto verbal.

Philippe Hamon sugere que "a presença da arquitetura na literatura parece estar duplamente confinada e circunscrita por gêneros epidíticos. Mais especificamente, está vinculada à prática da écfrase". 7 Para Lars Elleström, mesmo que alguém "não tenha intenção de extrapolar a noção de écfrase, deve-se admitir que é possível, habitual e relevante teorizar além das fronteiras convencionais" do termo. Afinal, "independentemente das circunstâncias, poemas que representam pinturas são apenas uma parcela ínfima do amplo campo de representação de mídias complexas". ${ }^{8}$ Ainda que, para James Heffernan, a capacidade de "falar sobre, por e para obras de arte" seja um aspecto fascinante da écfrase, o problema

\footnotetext{
${ }^{5}$ HARRIES. The Ethical Function of Architecture, p. 368.

${ }^{6}$ HARRIES. The Ethical Function of Architecture, p. 368.

7 “ [...] the presence of architecture in literature would appear to be doubly confined and circumscribed by the epideictic genres. More specifically, it is linked to the practice of ekphrasis" (HAMON. Expositions, p. 24, tradução minha).

8 "Even if one does not want the notion of ekphrasis to be extended that far for historical or other reasons, it must be acknowledged that complex representations of media products are possible, common, and worthwhile to theorize about far beyond the conventional borders of ekphrasis. In all circumstances, poems representing paintings only constitute a tiny fragment of the broad field of complex media representation" (ELLESTRÖM. Media Transformation, p. 33, tradução minha).

9 "Ekphrasis does not only speak about works of art but also to and for them" (HEFFERNAN. Museum of words, p. 7, tradução minha).
} 
da combinação entre arquitetura e écfrase é fundamentado pela sua enfática afirmação de que a arquitetura não pode ser representada, por não se tratar de uma mídia representativa. ${ }^{10}$ Apesar da bem-sucedida tentativa de Claus Clüver de ampliar a definição de écfrase proposta por Heffernan - "representação verbal de uma representação visual" "1 para "representação verbal de configurações reais ou fictícias compostas numa mídia visual não-cinética", ${ }^{12}$ de modo a abarcar a arquitetura e as novas mídias, um dos problemas encontrados em ambas as definições de Heffernan e Clüver - reside no uso da palavra "representação". Para Heffernan, ela significa a qualidade material de um produto mimético e seus aspectos cognitivos. Já para Clüver, a écfrase não lida apenas com representação, mas pode também ser considerada uma "transposição intersemiótica", uma "tradução [...] de um sistema sígnico em outro baseado em mídia diferente". ${ }^{13}$ Elleström, por sua vez, sugere que a écfrase "não deve ser exclusivamente entendida como representação midiática", ${ }^{14}$ já que suas "discussões teóricas" e sua "prática analítica tendem a incluir não apenas a representação midiática, mas também a transmidiação", ${ }^{15}$ ou seja, "uma mídia-alvo pode representar e também transmidiar uma mídia-fonte" ${ }^{16}$ Essa discussão provocada por Elleström levou ao questionamento e revisão do entendimento de representação como o "ato de uma mídia apresentar uma outra mídia novamente" em favor do "processo" envolvido nesse ato. O entendimento do significado da palavra "representação" como processo dialoga com a explicação de Ruth Webb: na Antiguidade, a écfrase não buscava "representar, mas

\footnotetext{
${ }^{10}$ HEFFERNAN. Ekphrasis and Representation, p. 4.

${ }^{11}$ HEFFERNAN. Museum of words, p. 3.

12 “ [...] verbal representation of real or fictive configurations composed in a non-kinetic visual medium" (CLÜVER. Ekphrasis and Adaptation, p. 462, tradução minha).

13 " "...] intersemiotic transposition [...] the translation [...] from one sign system into another that is based on a different medium" (CLÜVER. Ekphrasis Reconsidered, p. ${ }^{21}$, tradução minha).

14 “[...] ekphrasis is not exclusively understood as media representation" (ELLESTRÖM. Media Transformation, p. 33, tradução minha).

15 “[...] [its] theoretical discussions [and its] analytical practice tend to include not only media representation but also transmediation" (ELLESTRÖM. Media Transformation, p. 33, tradução minha).

16 "[...] no conflict exists between a target medium both representing and transmediating a source medium" (ELLESTRÖM. Media Transformation, p. 33, tradução minha).
} 
sim exercer um efeito na mente da audiência de modo a imitar o ato de ver". ${ }^{17}$ Desse modo, para desenvolver adequadamente um modelo interpretativo de écfrase arquitetônica como recurso literário, é preciso resgatar as origens do termo "écfrase" como recurso retórico.

Webb admite a dificuldade de entendimento do termo como na Antiguidade e aposta em uma interpretação contemporânea de écfrase, baseada no aprofundamento das fontes teóricas da retórica antiga. ${ }^{18}$ Afinal, mesmo sendo a arquitetura negligenciada como objeto de écfrase em estudos contemporâneos, os "lugares feitos pelo homem" portos, colunas, cidades e edifícios - foram também fonte de inspiração para écfrases ${ }^{19}$ na Antiguidade. A exemplo do gênero de poemas sobre arquitetura conhecido como Architekturgedicht, Clüver explica que, desde que percebidas "como configurações significativas", estruturas arquitetônicas podem servir de fonte de inspiração para écfrases na contemporaneidade. ${ }^{20} \mathrm{E}$ ainda, a proposta de resgate da propriedade performativa da écfrase dos gregos, por Heidrun Führer e Bernadette Banaszkiewicz, ${ }^{21}$ dialoga com a premissa de Webb. É exatamente a recuperação dos conceitos enargia, performance e periegese que viabiliza o estudo da écfrase arquitetônica dentro dos estudos sobre a intermidialidade.

$\mathrm{Na}$ Antiguidade, com auxílio da enargia, a écfrase não somente representava um objeto específico, mas sim favorecia a capacidade performativa do locutor, graças a sua experiência e imaginação. Através do lampejo de uma cena, esse locutor, para atingir a mente da audiência, ativava a visualização de uma outra cena correspondente. Em poucas

17 " [...] does not seek to represent, but to have an effect in the audience's mind that mimics the act of seeing" (WEBB. Ekphrasis, Imagination and Persuasion in Ancient Rhetorical Theory and Practice, p. 38, tradução minha).

${ }^{18}$ WEBB. Ekphrasis, Imagination and Persuasion in Ancient Rhetorical Theory and Practice, p. 38.

${ }^{19}$ WEBB. Ekphrasis, Imagination and Persuasion in Ancient Rhetorical Theory and Practice, p. 80.

20 "Verbal representations of cathedrals or bridges or other architectural structures when viewed as meaningful configurations are ekphrases. There is a genre of Architekturgedicht (poems on architecture), most of which, like many (but by no means all) Bildgedichte (poems on pictures), are ekphrastic" (CLÜVER. Ekphrasis and Adaptation, p. 462, tradução minha, grifos do autor).

${ }^{21}$ FÜHRER; BANASZKIEWICZ. The Trajectory of Ancient Ekphrasis, p. 45-75. 
palavras, é a qualidade performativa da enargia que faz com que a definição do termo seja ressignificada, pois esse fenômeno midiático se dá no momento em que uma edificação se faz presente na mente do leitor.

No caso específico de écfrases sobre edificações, espaços em geral ou lugares geográficos na Antiguidade, o orador fazia uso da ferramenta epistemológica periegesis. De acordo com Webb, periegese é uma "forma elaborada de contar" em que o locutor guia o receptor "em torno da cena" ou "através do espaço". ${ }^{22}$ A periegese pode ser entendida como se fosse uma antecipação do recurso cinematográfico travelling. Portanto, ao intensificar a experiência arquitetônica de percorrer o entorno, o interior e o exterior de uma edificação, a periegese facilita o alcance de enargia em écfrases de sítios arquitetônicos.

Ainda que o estudo da écfrase na contemporaneidade seja enriquecido pela retomada dos papéis exercidos pela periegese e pelo poder performativo da enargia, esse resgate ainda não é suficiente para a elaboração de um modelo interpretativo para o estudo da écfrase arquitetônica. Além dos parâmetros utilizados para o estudo da presença da pintura na literatura - como os sugeridos por Hans Lund, ${ }^{23}$ Liliane Louvel $^{24}$ e Valerie Robillard ${ }^{25}$-, o modelo que estuda transferência de características de mídias, proposto por Elleström, norteou a delimitação das características intrínsecas da arquitetura a serem reveladas pela literatura.

Elleström combina características semióticas - que englobam aspectos icônicos, indexicais e simbólicos - e não semióticas - que dizem respeito aos fundamentos da mediação - em sua proposta. Para ele, as características pré-semióticas envolvem tanto as modalidades material, sensorial e espaçotemporal quanto seus respectivos aspectos qualificativos: contextual e operacional. Como a modalidade semiótica trata do sistema de significação e representação da mídia, a atribuição de sentido da mídia arquitetura se dá através de uma combinação de signos visuais e verbais com igual importância, peso e valor dentro da cadeia semiótica.

\footnotetext{
22 "[...] elaborate form of telling [that] casts the speaker as a guide showing the listener around the sight [or] through space" (WEBB. Ekphrasis, Imagination and Persuasion in Ancient Rhetorical Theory and Practice, p. 54, tradução minha).

${ }^{23}$ LUND. Text as Picture, p.50.

${ }^{24}$ LOUVEL. A descrição "pictural”, p. 207.

${ }^{25}$ ROBILLARD. In Pursuit of Ekphrasis, p. 53-72.
} 
Das características pré-semióticas, é relevante destacar que, na modalidade material, o produto final de uma edificação é composto por tijolo, cimento, argamassas, vidro, aço. Cabe também aqui mencionar a contribuição de Christian Norberg-Schulz ${ }^{26}$ empregada na análise linguística de écfrases arquitetônicas. $\mathrm{O}$ autor sugere que sejam tecidas relações entre a materialidade da estrutura construtiva e a estrutura linguística empregada em sua discussão. $\mathrm{O}$ autor define que lugares costumam ser designados através de substantivos, tais como ilha, floresta ou rua, e também parede, telhado, porta, uma vez que, em vez de falarmos de espaço no nosso dia a dia, falamos da relação entre coisas que estão, por exemplo, sobre, dentro, ou ao longo umas das outras. Portanto, se entendido como um sistema de relação, o espaço é indicado por preposições e locuções prepositivas. Já a tecnologia e as características empregadas em um ambiente construído pelo homem são indicadas através de adjetivos. No entanto, se a arquitetura é entendida como um processo que envolve várias etapas, a materialidade acontecerá também dentro da mente daqueles envolvidos no processo, assim como discutido pelos estudos cognitivos. Isso significa que a comunicação acerca da futura edificação só será bem-sucedida quando uma imagem mental comum puder ser incitada, que é o princípio básico da écfrase.

A investigação sobre o modo como os cinco sentidos afetam a produção e a recepção de uma edificação é imprescindível para a compreensão da modalidade sensorial. De acordo com Rudolf Arnheim, "um edifício é, em todos os seus aspectos, [uma ação] da mente humana. É uma experiência dos sentidos da vista e do ouvido, do [tato], do calor e do frio e do comportamento muscular, bem como dos pensamentos e esforços resultantes" ${ }^{27} \mathrm{Ou}$ seja, ao entrar em um edifício pronto para uso, muitas ações precisam ser tomadas em relação às affordances ${ }^{28} \mathrm{da}$ construção, tais como abrir a porta girando a maçaneta, apertar o botão do elevador, entre outras tantas. É preciso também investigar como a

\footnotetext{
${ }^{26}$ NORBERG-SCHULZ. Genius Loci, p.15-16.

${ }^{27}$ ARNHEIM. A dinâmica da forma arquitetônica, p. 13.

${ }^{28} \mathrm{O}$ termo é usado em inglês na bibliografia pertinente disponível em português. Uma affordance pode ser entendida como aquilo que cada mídia "dá conta". No caso da arquitetura é o potencial sugerido pela forma, previamente pensada por um designer, que será apresentada por determinado objeto de modo a ser manipulado por um agente conforme seu funcionamento. Por exemplo, uma maçaneta é redonda a fim de convidar o agente a girá-la. Para mais, ver: Gibson. The Ecological Approach to Visual Perception.
} 
quantidade de luz e a temperatura do ambiente afetam o usuário de tal edificação. A combinação de materiais entre si e com os elementos da natureza - condições meteorológicas -, aliada às atividades humanas que lá acontecerão, irá produzir diferentes aromas e odores que, sem dúvida, afetarão o sentido do olfato. ${ }^{29} \mathrm{~A}$ audição também será afetada pela combinação dos materiais utilizados, pelas intempéries e por atividades humanas. ${ }^{30}$ Apesar de não constar na proposta reducionista de Elleström - de acordo com o autor, não há nada a ser retirado, mas sim acrescido -, outro "sentido" a ser levado em consideração é o cinético, relacionado às atividades sensório-motoras, que será retomado ao abordarmos a noção de corporeidade. Essas experiências sensoriais dependem do contexto histórico, social e mesmo pessoal, como pontuado por Arnheim. Em poucas palavras, a mídia arquitetura é capaz de ativar praticamente todos os sentidos ao mesmo tempo através de seu produto final, que é a edificação propriamente dita.

A modalidade espaçotemporal faz com que a "estruturação do armazenamento de dados da percepção sensorial e da interface material seja revelada através de experiências e concepções de espaço e tempo". ${ }^{31}$ Além da relação entre volume, profundidade, largura e altura das edificações, ${ }^{32}$ o processo arquitetônico como um todo ocupa definitivamente diferentes tipos de espaços que, por sua vez, não podem ser dissociados do tempo. O arquiteto Steen Rasmussen argumenta que a relação tempo-espaço é uma das grandes dificuldades enfrentadas pelos arquitetos, cujo trabalho se destina "a perdurar até um futuro distante", já que "o edifício deve, de preferência, estar à frente do seu tempo quando é projetado, a fim de que possa acompanhar a marcha

\footnotetext{
${ }^{29}$ Por exemplo, quando o cheiro da comida que vem da cozinha impregna a roupa estendida no varal da área de serviço fechada devido à chuva forte.

${ }^{30}$ Por exemplo, quando o som da chuva que cai em um telhado de amianto afeta a concentração de alguém nos estudos.

31 " [... the spatiotemporal modality of media covers the structuring of the sensorial perception of sense-data of the material interface into experiences and conceptions of space and time" (ELLESTRÖM. Media Borders, Multimodality and Intermediality, p. 18, tradução minha).

32 Ver GLASER. Figures of Space, Figures of Time, para estudo detalhado das complexidades da questão espaço-tempo na reapresentação de catedrais góticas em diferentes gêneros de literatura.
} 
dos tempos enquanto estiver de pé". ${ }^{33}$ Para ele, "uma das provas de boa arquitetura é um edifício" que consegue manter o uso do espaço "tal como o arquiteto o planejou" ${ }^{34}$ ao longo dos tempos. Diferentemente da literatura e do cinema, que podem ser arquivados por meio de reprodução técnica, digital ou virtual, uma edificação nunca chega a alcançar um status de produto final, já que sua materialidade estará sempre vulnerável às intempéries e às mudanças socioeconômicas. Tal conclusão confirma que, além do entendimento das quatro modalidades de transferência de características de mídias, é de extrema importância a inclusão dos aspectos qualificativos contextuais de uma obra arquitetônica, em relação a sua origem, delimitação e uso, dentro de circunstâncias históricas, culturais e sociais específicas, ou seja, o posicionamento tanto por parte da produção quanto da recepção da obra arquitetônica. E ainda, os aspectos qualificativos operacionais devem ser observados em relação às características estéticas e comunicativas da edificação. Reside aqui a debatida problemática acerca da forma e da função da arquitetura, que inclui não somente as affordances, mas também o estudo de ergonomia, que determina a escala da edificação a partir do corpo humano.

A noção de corporéité foi proposta por Merleau-Ponty ${ }^{35}$ com o objetivo de incluir o corpo, além da mente, nos atos de percepção, experimentação e representação do mundo. Uma vez que a consciência não advém somente da mente, a noção de corporeidade tem como função garantir o papel central exercido pelo corpo no modo como experimentamos o mundo. Corpo e mente possuem uma ligação inextricável, portanto não podem ser dissociados. Diferentemente da dualidade proposta pelo pensamento cartesiano, sujeito e objeto são uma só unidade e, desse modo, devem ser tratados como duas facetas de uma mesma entidade incorporadas ${ }^{36}$ no mundo. Essa noção dá suporte à premissa de Rasmussen, de que "não é suficiente ver arquitetura; devemos vivenciá-la [...] devemos residir nos aposentos, sentir como nos

\footnotetext{
${ }^{33}$ RASMUSSEN. Arquitetura vivenciada, p. 10.

${ }^{34}$ RASMUSSEN. Arquitetura vivenciada, p. 12.

${ }^{35}$ MERLEAU-PONTY. Phénoménologie de la perception.

${ }^{36}$ AUSLANDER. Theory for Performance Studies, p. 136-139. O referencial teórico investigado usa o termo corporéité em inglês: embodiment. Optamos por traduzir o termo embodied como "incorporado".
} 
circundam, observar como nos levam naturalmente de um para outro". ${ }^{37}$ A arquitetura deve ser explorada fisicamente através dos sentidos, pois "devemos estar conscientes dos efeitos [causados por diferentes texturas], descobrir por que certas cores foram usadas e não outras, [...] devemos sentir a grande diferença que a acústica faz em nossa concepção de espaço". ${ }^{38}$ Ou seja, além de contemplada, a arquitetura precisa ser fisicamente experimentada. A corporeidade é, portanto, relevante para mostrar o efeito do corpo do usuário (ou leitor) em um ambiente arquitetônico.

Arnheim, por sua vez, explica que a experiência arquitetônica consiste na "existência intemporal do edifício no espaço" e no "evento limitado no tempo de nele entrar", atravessá-lo e usá-lo, "por parte do visitante". ${ }^{39}$ Ele compara essa "experiência arquitetônica de atravessar um edifício" à técnica cinematográfica travelling, que tem relação com aquele recurso utilizado na retórica para descrever lugares, paisagens e edificações: a periegese. O percurso ao redor e dentro da edificação possibilitará essa percepção de novas perspectivas a partir de diferentes pontos de vista. É relevante pontuar que o termo "perspectiva" apresenta diferentes conotações em diferentes disciplinas. James Elkins afirma que a "perspectiva direciona nosso olhar e organiza nossos pensamentos". ${ }^{40}$ A dificuldade em se pensar através e em torno de um determinado ponto de vista se dá porque, na grande maioria das vezes, nas artes visuais, a perspectiva é confinada em si mesma. Hans Belting ${ }^{41}$ chama a atenção para o fato de que, apesar de "inocupável", o ponto de fuga da perspectiva clássica na pintura possibilita ao espectador objetificar-se externamente a determinada imagem, imagem essa que faz uma declaração dêitica de um dado local em um exato instante no tempo. O argumento em prol deste ponto de vista único e individualizado nas artes visuais dialoga com a noção de focalização desenvolvida pelos estudos de narratologia. Segundo Monica Fludernik, ${ }^{42}$ a focalização dos trechos irá preencher

\footnotetext{
${ }^{37}$ RASMUSSEN. Arquitetura vivenciada, p. 32.

${ }^{38}$ RASMUSSEN. Arquitetura vivenciada, p. 32.

${ }^{39}$ ARNHEIM. A dinâmica da forma arquitetônica p. 100.

40 "[...] perspective directs our eyes and orders our thoughts" (ELKINS. The Poetics of Perspective, p. 212, tradução minha).

${ }^{41}$ BELTING. Florence and Baghdad.

${ }^{42}$ FLUDERNIK. Description and Perspective.
} 
lacunas em relação à função dentro do enredo de romances. Esse jogo provocado pela perspectiva permite o posicionamento do observador em lugares em que nunca esteve antes. Ou seja, como na écfrase, tal jogo resulta na indissolúvel relação entre presença e ausência.

Uma écfrase de arquitetura pode ser análoga à écfrase de um artefato bidimensional, quando apresentada como se fosse uma pintura ou uma fotografia, ou mesmo análoga a uma écfrase de artefato tridimensional, quando apresentada como se fosse uma escultura. Esse tipo de écfrase pode até ser investigado com o auxílio dos parâmetros já consolidados dentro dos estudos sobre écfrase. Entretanto, quando toda a potencialidade da mídia arquitetura é expressa por meio de palavras, a écfrase é capaz de desencadear uma interação entre a personagem, e consequentemente do leitor, e o processo arquitetônico ou a edificação per se. O reconhecimento da libertação da écfrase de sua limitação ao objeto de arte como fonte de inspiração, assim como de suas delimitações referenciais, possibilitou o modelo aqui proposto. Esse tipo de écfrase sobre arquitetura almeja a inclusão de novos parâmetros de análise, tais como as modalidades da mídia arquitetura, a noção de corporeidade e as diferentes facetas do termo "perspectiva". As tipologias propostas por este modelo compreendem tanto as écfrases sobre arquitetura, quanto as écfrases de arquitetura; aquelas demandam conhecimento prévio específico - cultural ou técnico -, e estas tiram proveito de toda a potencialidade das especificidades da mídia arquitetura, principalmente a corporeidade. Assim sendo, todas foram classificadas e tratadas como casos de écfrases arquitetônicas.

Para um entendimento das características intrínsecas à arquitetura e delimitação de suas especificidades potencialmente reveladas pela literatura, além dos parâmetros já consolidados dentro dos estudos sobre écfrase, os seguintes aspectos foram levados em conta: (a) as citações de nomes de arquitetos e edifícios; (b) as repetições significativas; (c) as possíveis similaridades estruturais com as obras-fontes; (d) a importância das formas de representação técnica e diagramática; (e) a negociação verbal para a atribuição de sentidos ao longo do processo arquitetônico; (f) o léxico utilizado a partir da materialidade revelada nos níveis físico (por meio de materiais como o tijolo e o cimento) e virtual (por meio daquilo que está na mente do cliente e do arquiteto); (g) as funções de linguagem; (h) o apelo aos sentidos, que, no caso da arquitetura, é revelado por meio da corporeidade, pois, ao promover 
todos os cinco sentidos e também o sensório-motor, resgata a qualidade performativa da écfrase, principalmente através da periegese; (i) a tridimensionalidade espacial promovida pela volumetria e pelas relações entre altura, largura, profundidade; (j) a indissociável relação tempoespaço do ambiente construído pelo homem marcada por indicadores dêiticos; (k) a função das affordances e da ergonomia em relação à forma estética da obra arquitetônica; (1) o jogo entre a perspectiva de acordo com estudos literários, a focalização do trecho em questão e o lugar de posicionamento da persona literária em relação ao ponto de fuga que irá guiar o olhar do receptor; e, finalmente, $(\mathrm{m})$ o cruzamento de todas evidências anteriores com a contextualização histórica, cultural e social (posicionamento) do processo arquitetônico. Desse modo, o modelo interpretativo de écfrase arquitetônica aqui delineado compreende quatro tipologias: contemplativa, performativa, simbólica e técnica.

As écfrases arquitetônicas contemplativas são aquelas em que a personagem contempla uma edificação ou paisagem urbana a partir de um ponto de vista específico, sem que o agente focalizador interaja fisicamente com o sítio arquitetônico focalizado. As écfrases arquitetônicas performativas são aquelas que acontecem quando o observador, seja o narrador, seja a personagem, está fisicamente dentro de um sítio arquitetônico. Ao circular pela edificação, entrando, saindo, subindo, descendo, como que em um tour, o leitor deixa de ser um mero espectador e envolve-se em uma performance virtual. Como o conhecimento prévio do leitor é de suma importância nos estudos sobre écfrase, as passagens ecfrásticas que demandam do leitor uma maior bagagem cultural ou técnica, foram nomeadas, respectivamente, écfrase arquitetônica simbólica e écfrase arquitetônica técnica.

Neste texto, pretendemos demonstrar, em uma classificação horizontal e não hierárquica, o modelo interpretativo em diferentes trechos ecfrásticos das biografias romanceadas: Flores raras e banalíssimas e $A$ arte de perder, como ilustrado a seguir.

As écfrases arquitetônicas contemplativas são análogas à écfrase de acordo com a definição de Clüver e com as origens do termo na Antiguidade. Essa tipologia pode ser revelada de duas maneiras distintas. A primeira acontece quando a edificação é reapresentada como se fosse uma pintura ou uma fotografia, ou seja, como um artefato bidimensional em que o focalizador (o interlocutor: narrador ou personagem) da écfrase encontra-se do lado de fora do sítio arquitetônico em uma performance 
como se estivesse em uma galeria de arte a observar um artefato. A segunda maneira acontece quando a edificação é reapresentada como $s e$ fosse uma escultura, ou seja, como um artefato tridimensional que, apesar de ser admirado em sua totalidade, não chega a ser fisicamente vivenciado.

Uma vez que o agente focalizador interage com a arquitetura como se estivesse assistindo a uma peça teatral, em que a edificação faz as vezes de palco, nessa tipologia de écfrase arquitetônica, a edificação irá exercer o papel de palco, e o agente focalizador, o de espectador. No romance $A$ arte de perder, o narrador relata a primeira vez que as personagens Lota e Elizabeth, juntas, visitaram Minas Gerais. A silhueta da pequena cidade é descrita pelos olhos da poeta: "No vale abaixo, em meio ao verde, um mar de telhados de telhas vermelhas. Igrejas mantinham-se como fortalezas altas sobre afloramentos de pedras". ${ }^{43}$ Sob a ótica de Elizabeth, que se hospeda no Grande Hotel de Ouro Preto, projetado pelo arquiteto Oscar Niemeyer, o narrador explica que, apesar de "pura vaidade", a obra modernista implantada em uma cidade colonial era agradável e elegante:

O terraço do hotel em que estavam tinha uma vista panorâmica da cidade em meio a uma vegetação tropical, com um pano de fundo de uma serra alta e irregular. Três séculos antes, eles tinham extraído ouro e construído esta opulenta cidade, embora, segundo Lota, as construções agora tivessem se deteriorado de tal modo que não havia conserto. $^{44}$

O saguão do hotel era uma comprida caixa de vidro banhada com luz difusa, e não tinha nada além de umas poucas peças esparsas de mobiliário, colocadas aqui e ali, aparentemente mais para efeito visual do que para conforto dos viajantes. Lá longe, na outra extremidade do espaço vazio, ficava a recepção, uma bancada de pedra branca. ${ }^{45}$

${ }^{43}$ SLEDGE. A arte de perder, p. 115.

${ }^{44}$ SLEDGE. $A$ arte de perder, p. 117.

${ }^{45}$ SLEDGE. A arte de perder, p. 118. 
Ao observar, a partir do terraço do hotel, a implantação em uma "serra alta e irregular" coberta pela "vegetação tropical" pelo lado de fora, a personagem constata que aquela cidade havia sido muito rica. Ao se voltar para o interior do "saguão do hotel" com "poucas peças esparsas de mobiliário", a poeta percebe que a "luz difusa" provocada pela "caixa de vidro" e pelo "espaço vazio" favorece mais a forma do que a função. A personagem Elizabeth permanece fisicamente em um ponto fixo dentro da construção, enquanto o narrador relata os detalhes por ela percebidos tanto no exterior quanto no interior da edificação. Essa focalização, que parte de um ambiente natural externo e adentra um interior minimalista, evidencia características estilísticas intrínsecas à arquitetura modernista brasileira, em uma écfrase arquitetônica do tipo contemplativa.

As écfrases arquitetônicas performativas acontecem quando o leitor é guiado através, dentro e fora do sítio arquitetônico em uma performance mental. A experiência sensório-motora complementa a sensorial por meio da periegese e performance corporal à medida que o leitor se envolve mentalmente de modo a interagir com a obra arquitetônica ao longo do trajeto percorrido. Também no romance escrito por Michael Sledge, as duas protagonistas se hospedam em outro hotel, uma "monstruosidade modernista", ${ }^{46}$ localizado nas imediações de Juiz de Fora. ${ }^{47}$ A personagem Elizabeth pondera que o "Brasil tinha desperdiçado uma riqueza tão grande com suas pretensões a uma grandeza que nunca se materializaria ou não poderia ser sustentada além de um momento histórico". Para ela, os "palácios imperiais de Petrópolis", o "grande teatro de ópera de Manaus, no meio da Floresta Amazônica", e até mesmo sua querida Ouro Preto, estava tudo "fadado a cair em decrepitude, exatamente como também cairiam, sem dúvida alguma, todos aqueles monumentos ao modernismo". ${ }^{48}$ Para a poeta, aquele hotel "era um dos lugares mais medonhos já concebidos e executados", tanto que, ao percorrer os "corredores escuros de concreto cheirando a mofo, tinha se sentido uma formiga percorrendo trilhas cavadas na terra, ou

\footnotetext{
${ }^{46}$ SLEDGE. $A$ arte de perder, p. 127.

${ }^{47}$ Não foi encontrada nenhuma referência de obra de hotel modernista significativa em Juiz de Fora, mas existe um hotel situado em Cataguases, cidade que tem acervo considerável de obras modernistas influenciadas pela arquitetura carioca daquele período, que se encaixa na écfrase em questão.

${ }^{48}$ SLEDGE. A arte de perder, p. 129.
} 
um mineiro em túneis prestes a desmoronar". ${ }^{49}$ Elizabeth comenta com Lota que aquele "hotel faz com que [ela se] sinta um canário asfixiando em uma mina". Lota responde que "o mau modernismo é terrível; [machuca] a alma". Elizabeth argumenta que o prédio "é exatamente o oposto de tudo maravilhoso que existe na casa [Samambaia]: a leveza e a transparência, a luminosidade" ${ }^{50} \mathrm{O}$ posicionamento da personagem Elizabeth em relação às circunstâncias históricas, culturais e até mesmo sociais do hotel modernista construído nos arredores de uma pequena cidade em Minas Gerais é revelado com o auxílio dos aspectos qualificativos contextuais (aqueles de cunho histórico, cultural e social). Já ao comparar as sensações da poeta às de um "mineiro" que trabalha debaixo da terra e às de animais pequenos como a formiga e o canário, o diálogo entre as personagens, por um lado, expressa a corporeidade desencadeada pela claustrofobia causada pela escuridão e pelos odores durante o percurso pelos corredores da edificação e, por outro, valoriza a harmonia da casa em que elas viviam, localizada nos arredores de Petrópolis, conhecida como Samambaia. Em suma, a combinação da passagem sobre a arquitetura brasileira com o diálogo sobre as sensações claustrofóbicas, durante o trajeto pelos corredores do hotel, pode ser lida como uma écfrase arquitetônica do tipo performativa.

As écfrases arquitetônicas simbólicas, ou aquelas atribuídas a um conhecimento cultural, são caracterizadas pela ênfase dada ao significado simbólico da obra arquitetônica. No romance $A$ arte de perder, o narrador focaliza a percepção da personagem Elizabeth da paisagem enquadrada pela janela do táxi no percurso da "extensão do aterro" durante o trajeto do cais, localizado na ilha Brocoió, até Copacabana. Além do apelo aos sentidos da audição, provocado pela sensação de alta velocidade do carro guiado "como se [o motorista] estivesse decidido a quebrar a barreira do som", e do tato, provocado por "seu punho [que] jazia fechado na garra gelada" ${ }^{11}$ do amigo Cal, a paisagem urbana emoldurada pela janela do carro carrega um significado simbólico, pois apresenta, de um lado, um dos mais importantes monumentos católicos erguidos em um país cheio de idiossincrasias religiosas e, do outro, o parque, que surgiu a partir de um aterro sanitário, com o objetivo de promover uma imagem positiva

\footnotetext{
${ }^{49}$ SLEDGE. $A$ arte de perder, p. 128.

${ }^{50}$ SLEDGE. $A$ arte de perder, p. 130.

${ }^{51}$ SLEDGE. $A$ arte de perder, p. 223.
} 
de um controverso político. O Parque do Flamengo não é reapresentado de maneira poética, porém o enaltecimento da sensação de "falsidade dos monumentos", ${ }^{52}$ provocada pelos símbolos nacionais - a estátua do Cristo Redentor - e pessoais - Carlos Lacerda como figura emblemática da melhoria do espaço urbano e do lazer carioca nos anos 1950 -, fazem da verbalização do entorno do Parque do Flamengo um exemplo de écfrase do tipo simbólica.

As écfrases arquitetônicas técnicas, ou aquelas atribuídas ao conhecimento técnico, cujas fontes visuais são identificadas por leitores pertencentes a uma comunidade interpretativa específica, são caracterizadas pela demanda de letramento técnico e/ou conhecimento prévio do discurso arquitetônico. Em Flores raras e banalíssimas, o narrador delineia, de maneira fidedigna, o processo arquitetônico do Parque do Flamengo desde sua concepção. No trecho em que as obras estão a todo vapor, o urbanista Afonso Reidy, em busca de uma solução para o problema da iluminação, sugere a Lota procurar o renomado arquiteto norte-americano Phillip Johnson, que recomenda Richard Kelly, um especialista em luminotécnica. O designer aceita o desafio e afirma que "a oportunidade de iluminar aquela orla marítima absolutamente deslumbrante era única na vida de um especialista", pois "da janela de seu quarto na Glória via a luz chegando ao parque, ressaltando os contornos da vegetação sem revelar a fonte luminosa. Imediatamente [Lota] começou a esboçar um sistema que iluminasse como uma noite de luar intenso". ${ }^{33}$ Aquela "ideia espetacular" ganha forma:

Postes da maior altura possível, no menor número possível, para suporte de luminárias de rendimento máximo. Ou seja, apenas cento e doze postes de quarenta e cinco metros, suportando uma armação com seis projetores, substituiriam os mil e oitocentos postes previstos. Os projetores seriam dotados de lâmpadas de vapor de mercúrio de mil watts e envolvidos por tambores antiofuscantes. Sim, ela [Lota] ia lutar com unhas e dentes por aquele projeto. Nada no Aterro seria banal. ${ }^{54}$

\footnotetext{
${ }^{52}$ SLEDGE. A arte de perder, p. 223.

${ }^{53}$ OLIVEIRA. Flores raras e banalíssimas, p. 156.

${ }^{54}$ OLIVEIRA. Flores Rara e banalissimas, p. 156.
} 
A partir da ótica da personagem Lota, o narrador explica que "iluminar não era só clarear [...], a técnica tinha que ser submetida ao olhar sensível e criativo do artista", pois o parque "havia se convertido era uma obra de vanguarda". ${ }^{55}$ Ainda que as características dos postes sejam detalhadamente especificadas através de quantidade, "cento e doze postes"; altura, "quarenta e cinco metros"; material, "lâmpadas de vapor de mercúrio"; e capacidade, "mil watts", a passagem demanda familiaridade com a luminotécnica para que as peculiaridades de tais postes se façam presentes na mente do leitor. Portanto, o trecho sobre a iluminação de vanguarda pode ser lido como uma écfrase arquitetônica técnica.

Apesar do estilo literário diferenciado da autora brasileira e do autor norte-americano, a arquitetura é igualmente determinante em ambos os enredos. Visto que uma tipologia pode ser intercalada ou justaposta a outra em um mesmo trecho ecfrástico, a classificação proposta demonstra que, por mais útil que sejam as categorizações para o aprofundamento de uma investigação, as delimitações nunca devem ser estanques, e sim um ponto de partida. Uma das maneiras de a arquitetura ser revelada por meio de palavras é a écfrase arquitetônica. Acreditamos que o estímulo provocado por esse exercício cognitivo estimule a imaginação do leitor, seja ele arquiteto ou não, e que o entendimento mútuo provocado pela enargia, que ocorre quando a imaginação do leitor é envolvida pela do autor, seja análogo à interação bem-sucedida entre cliente e arquiteto no processo arquitetônico. Em suma, acreditamos que o aspecto mais fascinante da écfrase arquitetônica é a capacidade de a literatura falar sobre, por e para a arquitetura.

\section{Referências}

ALBERTI, Leon Battista. Da pintura. Tradução de Antônio da Silveira Mendonça. Campinas: Editora Unicamp, 1999.

ARNHEIM, Rudolf. A dinâmica da forma arquitetônica. Lisboa: Presença, 1988.

AUSLANDER, Philip. Theory for Performance Studies. New York: Routledge, 2008.

${ }^{55}$ OLIVEIRA. Flores Raras e banalíssimas, p. 157. 
BELTING, Hans. Florence and Baghdad: Renaissance Art and Arab Science. Translated by Deborah Lucas Schneider. Cambridge: The Belknap Press of Harvard University Press, 2011.

BISHOP, Elizabeth. Song for a Rainy Season. The New Yorker, New York, p. 40,8 Oct. 1960.

CLÜVER, Claus. Ekphrasis and Adaptation. In: LEITCH, Thomas (Ed.). The Oxford Handbook of Adaptation Studies. New York: Oxford University Press, 2016. p. 459-477.

CLÜVER, Claus. Ekphrasis Reconsidered: on Verbal Representations of Non-Verbal Texts. In: LAGERROTH, Ulla-Britta; LUND, Hans; HEDLING Erik (Ed.). Interart Poetics: Essays on the Interrelations between the Arts and Media. Amsterdam; Atlanta: Rodopi, 1997. p. 19-33.

COLOMINA, Beatriz (Ed.). Architectureproduction. New York: Princeton Architectural Press, 1988.

ELKINS, James. The Poetics of Perspective. Ithaca: Cornell University Press, 1994.

ELLESTRÖM, Lars. Media Borders, Multimodality and Intermediality. New York: Palgrave Macmillan, 2010.

ELLESTRÖM, Lars. Media Transformation: the Transfer of Media Characteristics among Media. Houndmills: Palgrave Macmillan, 2014.

FLUDERNIK, Monika. Description and Perspective: the Representation of Interiors. Style, v. 48, n. 4, p. 461-478, Winter 2014.

FÜHRER, Heidrun; BANASZKIEWICZ, Bernadette. The Trajectory of Ancient Ekphrasis. In: JEDLICKOVA, Alice (Ed.). On Description. Prague: Akropolis, 2014. p. 45-75.

GIBSON, James Jerome. The Ecological Approach to Visual Perception. London: Lawrence Erlbaum Associates, 1986.

GLASER, Stephanie A. Figures of Space, Figures of Time: Gothic Architecture, Enaergeia, and Periegesis. In: FÜHRER, Heidrun (Ed.). Making the Absent Present: Challenging Contemporary Concepts of Ekphrasis. Lund: Intermedia Studies Press, 2017. In press. 
HAMON, Philippe. Expositions: Literature and Architecture in Nineteenth-Century France. Translated by Katia Sainson-Frank and Lisa Maguire. Berkerley: University of California Press, 1992.

HARRIES, Karsten. The Ethical Function of Architecture. Cambridge, MA: The MIT Press, 1997.

HEFFERNAN, James A. W. Ekphrasis and Representation. New Literary History, n. 22, p. 297-316, 1991.

HEFFERNAN, James A. W. Museum of words: the poetics of ekphrasis from homer to ashbery. Chicago: University of Chicago Press, 1993.

LOUVEL, Liliane. A descrição "pictural”: por uma poética do iconotexto. Tradução de Luiz Cláudio Vieira de Oliveira. In: ARBEX, Márcia (Org.). Poéticas do visivel: ensaios sobre a escrita e a imagem. Belo Horizonte: FALE/UFMG, 2006. p. 191-220.

LOUVEL, Liliane. Le tiers pictural: pour une critique intermédiale. Rennes: Presses Universitaires de Rennes, 2010. DOI: https://doi. org/10.4000/books.pur.41005.

LUND, Hans. Text as Picture: Studies in the Literary Transformation of Pictures. Translated by Kacke Götrick. Lewiston; Queenston; Lampter: The Edwin Mellen Press, 1992.

MERLEAU-PONTY, Maurice. Phénoménologie de la perception. Paris: Gallimard, 1945.

NORBERG-SCHULZ, Christian. Genius Loci: Towards a Phenomenology of Architecture. New York: Rizzoli, 1980.

OLIVEIRA, Carmen. Flores raras e banalíssimas: a história de Lota de Macedo Soares e Elizabeth Bishop. Rio de Janeiro: Rocco, 1995.

RASMUSSEN, Steen E. Arquitetura vivenciada. 2. ed. Tradução de Álvaro Cabral. São Paulo: Martins Fontes, 2002.

RASMUSSEN, Steen E. Understanding Architecture. Cambridge, MA: The MIT Press, 1957.

ROBILLARD, Valerie. In Pursuit of Ekphrasis (an Intertextual Approach). In: ROBILLARD, Valerie; JONGENEEL, Els (Ed.). Pictures into Words: Theoretical and Descriptive Approaches to Ekphrasis. Amsterdam: VU University Press, 1998. p. 53-72. 
SLEDGE, Michael. A arte de perder. Tradução de Elisa Nazarian. São Paulo: Leya, 2011.

SLEDGE, Michael. The More I Owe You. Berkeley: Counterpoint, 2010. VIEIRA, Miriam de Paiva. Écfrase: de recurso retórico na antiguidade a fenômeno midiático na contemporaneidade. Todas as Letras, São Paulo, v. 19, n. 1, p. 45-57, 2017. Disponível em: <http://editorarevistas. mackenzie.br/index.php/tl/article/view/9955/6384>.

WEBB, Ruth. Ekphrasis, Imagination and Persuasion in Ancient Rhetorical Theory and Practice. Surrey: Ashgate, 2009. 